\title{
The sustainability-peace nexus in crisis contexts: how the Rohingya escaped the ethnic violence in Myanmar, but are trapped into environmental challenges in Bangladesh
}

\author{
Saleh Ahmed ${ }^{1}$ (D) William Paul Simmons ${ }^{2,3} \cdot$ Rashed Chowdhury $^{4} \cdot$ Saleemul Huq ${ }^{5}$
}

Received: 3 October 2020 / Accepted: 7 April 2021 / Published online: 19 April 2021

( $)$ The Author(s), under exclusive licence to Springer Japan KK, part of Springer Nature 2021

\begin{abstract}
Because of ethnic and cultural violence in Myanmar, approximately a million Rohingya fled to neighboring Bangladesh starting from August 2017, in what the UN has called a "textbook example of ethnic cleansing". Those arriving in Bangladesh were able to escape decade-long ethnic violence in Myanmar, but the Rohingya's immediate destination, Cox's Bazar district is one of the most climate-vulnerable and disaster-prone areas in Bangladesh. Currently, they have been subjected to extreme rainfalls, landslides, and flashfloods. With the COVID-19 pandemic, they continue to face fear and further marginalization in resource-constrained Bangladesh, as well as increased vulnerability due to tropical cyclones, flashfloods, and landslides. The Rohingya in southeast Bangladesh are now at the epicenter of a humanitarian and sustainability crisis. However, their situation is not entirely unique. Millions of displaced, stateless or refugees around the world are facing multi-dimensional crises in various complex geopolitical, and climatic situations. Using the theoretical lens of political ecology and critical development studies, this paper analyzes the sustainability-peace nexus for millions of Rohingya in Myanmar and in Bangladesh. This paper is based on information from various sources, including three ethnographic field visits in recent years, which helped to get local insights into the current sustainability challenges in this humanitarian context. The core arguments of this paper suggest that sustainability-peace nexus will especially be compromised in climate-vulnerable resource-constrained conditions. To overcome this challenge, decolonizing Rohingya solutions would be critical, by engaging the Rohingya in the process of development and meaningful change, which can affect their lives, livelihoods, and wellbeing. Even though this paper has a specific geographical focus, the insights are relevant in parts of the world facing similar social, economic, political, and environmental challenges.
\end{abstract}

Keywords Climate change $\cdot$ Ethnic violence $\cdot$ Rohingya $\cdot$ Southeast Bangladesh $\cdot$ Sustainability-peace nexus

Handled by Ayyoob Sharifi, Hiroshima University IDEC Higashi

Hiroshima, Japan.

Saleh Ahmed

salehahmed@boisestate.edu

William Paul Simmons

williamsimmons@email.arizona.edu

Rashed Chowdhury

rashed@hawaii.edu

Saleemul Huq

saleemul.huq@icccad.net

1 School of Public Service, Boise State University, Boise, ID 83725, USA
2 Gender and Women's Studies, University of Arizona, Tucson, AZ 85721, USA

3 Human Rights Practice Program, University of Arizona, Tucson, AZ 85721, USA

4 Pacific ENSO Applications Climate Center, Joint Institute for Marine and Atmospheric Research, University of Hawaii At Manoa, Honolulu, HI 96822, USA

5 International Centre for Climate Change and Development (ICCCAD), Independent University, Bangladesh (IUB), Dhaka 1229, Bangladesh 


\section{Introduction}

People, poverty, and their environment are deeply interlinked (Stockholm Resilience Centre 2018). However, these interlinkage or dependencies are often overlooked as the contributors of socio-political instability across regions (Downing 2020). For several decades, scholars have attempted to demonstrate the importance of integrating social, environmental, and economic dimensions into understanding sustainability (Berkes and Folke 1998; Niesenbaum 2020). However, it is equally important to include "peace" into the discussion of sustainability, but peace often remains secondary to other political elements.

The contemporary dynamics of global change and geopolitics highlights the pressing needs for unpacking the potential interrelationships and interdependencies of sustainability and peace (Virji et al. 2019), as numerous regions across the world are not only exposed to various weather and climate-related challenges (IPCC 2018), but also conflicts and violence in different forms (Schleussner et al. 2016). It is particularly important in the Global South, where people are struggling with limited resources under various climate-stressed conditions. For instance, decadeslong droughts have fueled mass-scale communal and ethnic conflict and violence in some parts of Middle East, including Syria (Gleick 2019), in the Horn of Africa (Solomon, Birhane et al. 2018), and in the Sahel (Raleigh 2010). Previous research has demonstrated that existing and increasing environmental stresses can directly or indirectly contribute to conflict (Barnett and Adger 2007; Schleussner et al. 2016) by undermining the opportunities of peace and security (Virji et al. 2019). These environmental stresses usually contribute to conflicts, violence, or animosity and mistrust under certain socio-economic, and political conditions (Abrahams 2019) especially in climate-vulnerable low-income developing societies, where political and institutional structures are fragile enough to be vulnerable to conflict and violence (Koubi 2019; Schleussner et al. 2016). Therefore, peace is central to the local and global development processes. For example, in the United Nations Sustainable Development Goals (UN 2015a), Goal 16: Peace, Justice and Strong Institutions directly talks about peace under the framework of sustainable development.

Conceptually, it is customary to distinguish between "negative peace" and "positive peace" (Galtung 1969). Negative peace is the absence of armed conflict, and positive peace entails the establishment and restoration of harmonious relationships and creation of social systems that address the underlying causes of all forms of conflicts and violence in a specific location (Galtung 1969). Positive peace contributes to building and sustaining peaceful communities (Amadei 2019).
Most existing scholarship largely focuses on the nexus between climate and conflict; however, fails to capture possible broader meanings of the sustainability-peace nexus (Virji et al. 2019). The sustainability-peace nexus needs to be informed by both negative and positive peace. Also, research needs to unpack different subcomponents of the nexus using various transformative and transdisciplinary approaches (Virji et al. 2019).

Using the Rohingya refugee crisis as a case study, this paper analyzes the sustainability-peace nexus by focusing on both negative peace in Myanmar and attempts to create scenarios for positive peace in Bangladesh. Even though this paper has a geographical focus, insights are relevant to the larger discussion on sustainability-peace nexus in other parts of the world, where people and states are facing similar social, political, economic, and environmental challenges.

\section{Rohingya crisis in South and Southeast Asia}

The Rohingya - a predominantly Muslim ethnic minority with roots in Bengali culture-have lived in northern Rakhine State in largely Buddhist Myanmar for hundreds of years. ${ }^{1}$ However, over the last several decades, they have increasingly faced systematic and widespread ethnic and religious persecutions. Denied citizenship by Myanmar's government since 1982, the Rohingya are often labeled the largest stateless population on the planet (Cheung 2011; United Nations Human Rights Council 2018). Their lack of legal citizenship in Myanmar stands as a marker for 'illegal' status, which has served to alienate them and contribute to both structural and cultural violence (Zawacki 2013). The Rohingya are deprived of many civil, political, economic, social, and cultural rights and face restrictions on free movement, education, assembly, and religion in their home country of Myanmar (United Nations Human Rights Council 2016, 2018). Also, there is a patchwork of laws on marriages and family size. Often, Rohingya Muslims have to obtain approval for marriage and only after the woman is photographed without a headscarf (or Hijab). In some areas in Myanmar, Rohingya are not allowed to have more than two babies and their babies are not registered with the government (Kashyap 2013). Living conditions have been substandard even compared to the rest of Rakhine state, the poorest or second poorest in Myanmar.

\footnotetext{
1 There are 135 registered ethnicities in the country: the Bamar who are mostly Buddhist are the overwhelming majority. Rakhine state is made up of Buddhist Rakhine, Muslim Rohingya and Muslim Kaman. There are also about 20,000 Hindu that are not registered as a formal ethnicity.
} 
Table 12014 census contrasting Rakhine state with the national average (in \%)

\begin{tabular}{llll}
\hline Measure & Rakhine & National & Comments \\
\hline Improved drinking water & 37.8 & 69.5 & Lowest in Myanmar \\
Improved sanitation & 31.8 & 74.3 & \\
Electricity access & 12.8 & 32.4 & \\
Mobile phone access & 15.8 & 35.9 & \\
Only thatch roofing & 72.5 & 35.1 & \\
Cooking with firewood & 88.9 & 69.2 & \\
No identity paper & 37.7 & 27.3 & \\
Mortality rate under & 75 & 72 & \\
5 year (per 1000) & & & \\
\hline
\end{tabular}

Source: UoM (2015)

Prior to the current Rohingya exodus, Rakhine state was the home of 3.2 million people. Among them, less than 2 million were ethnic Rakhine, 1.1 million were Rohingyas, and the remainder were Burman, or from other minority groups, such as Mro, Chin, Daignet, Kaman, and Hindu (UoM 2015). Rakhine state is one of the least developed states in Myanmar, which was clearly reflected by the 2014 census (Table 1).

Many in Rakhine state including most Rohingya are landless. The poverty likelihood in Maungdaw District, the largest in Rakhine Province and with predominate Rohingya population, was more than double the national average and the highest in Myanmar. The estimated poverty probability among the local is approximately $62 \%$. And at the same time, $19 \%$ of local households were "food poor" and struggle to have basic human needs (WFP 2017). Rohingyas often lack safe drinking water and their sanitation conditions are substandard with open defecation common in many areas. Medical facilities are meagre and substandard and few roads connect Rakhine to the rest of the country (United Nations Human Rights Council 2016, 2018).

The Rohingya are branded (cauterized-see Simmons 2011) as inferior by not being labeled as Rohingya by the government. Instead, they are called 'Bengalis' or sometimes 'illegal Bengalis,' a term denoting their alleged foreign status. They are deemed not to be 'Taingyintha' (natives of the soil) and their claims to have been living in the Burmese area since the eighth or ninth century are discounted by Burmese (modern day Myanmar) who claim they only came to the area from Bangladesh during colonial British rule in the nineteenth and twentieth centuries as laborers that usurped the position of local Buddhists (United Nations Human Rights Council 2016). Rohingya for years have been displaced from local villages into displacement camps, often at the urging of local residents and businesses who then appropriate their lands. Except for a brief period of reform in 2010 , Rohingya have not been allowed to vote or run for national office (United Nations Human Rights Council 2016).

The Rohingya are the "ultimate other" for the Myanmar/ Burmese majority: they look different, talk differently, pray differently, and come from a different place. As such there is little sympathy for them by most Burmese with public opinion solidly anti-Rohingya. Even peace activists and human rights activists who supported Aung San Suu Kyi, do not support the Rohingya (United Nations Human Rights Council 2016).

Anti-Muslim violence occurred in Myanmar in 1930 and 1938 as well as several times between 1990 and 2001. In 1978 and again in 1991-1992 approximately 250,000 Rohingya fled to Bangladesh because of rising persecution and violence, but then were repatriated after pressure on the Burmese government from the international community as well as deteriorating conditions in the refugee camps in Cox's Bazar, which is the district in southeast Bangladesh near the Myanmar-Bangladesh border. The violence worsened in 2012 with the Burmese army helped by local Buddhist militias attacking Rohingya villages killing hundreds and forcing many to flee to internally displacement camps or into neighboring Bangladesh (International Crisis Group 2019). Tensions based on socio-ethnic differences between Buddhist and Muslim communities in Rakhine State escalated dramatically in August 2017 when a group of Rohingya militants, calling themselves the Arakan Rohingya Salvation Army (ARSA) attacked Myanmar military and police outposts, killing 12 members of the armed forces. In response, the Myanmar military launched a brutal attack on Rohingya villages, targeting civilians and burning down more than 2,600 houses of suspected "violent attackers" causing nearly a million people to flee across the border to neighboring Bangladesh (United Nations Human Rights Council 2018). UN High Commissioner for Human Rights, Zeid Ra' ad alHussein, described this atrocity as a “...textbook example of ethnic cleansing" (UN 2017).

Desperate to flee Myanmar, Rohingyas built flimsy rafts from whatever materials they could find to cross the Naf River, bordering Myanmar and Bangladesh. Hundreds of refugees drowned in their attempts to cross the river (Ahmed and Alam 2017). Others walked for days through dense forests and hills and mountainous terrains to reach safety in Bangladesh, including pregnant women, children, the sick, and the elderly (Larmer 2017). Thousands crossed into Bangladesh regularly, braving dangerous voyages through jungle and mountain passes in the Mayu mountain range (Lewis 2017). One estimate suggests that almost 100,000 people crossed into Bangladesh in one day (Bandur 2018). In total, over 911,000 individuals have fled to Cox's Bazar district (ISCG 2019). According to the United Nations, the Rohingya crisis is among the largest and fastest-growing humanitarian emergencies in decades. The vast majority 
of those reaching Bangladesh are women and children, and more than 55 percent are under age 18 (UNHCR 2019).

Unfortunately, Rohingya are also victims of regional geopolitics and such factors will play a significant role in any potential repatriation. China and India have significant economic interests and investments in Myanmar (Ware and Laoutides 2018). Particularly, Rakhine State in Myanmar is crucial to economic development plans of both China (the Belt and Road Initiative) and India (the Act East Policy) (Taufiq 2019). These neoliberal development solutions are often criticized for not benefitting the local communities and being pursued in unsustainable ways. These development interventions directly or indirectly blamed for Myanmar's response to vacate large swaths of Rohingya lands for industrial development and foreign investments.

\section{Confluence of climate crisis and ethnic tensions}

Rakhine State is a coastal low-laying region susceptible to cyclones, floods, landslides, and saltwater intrusion (UN 2015b). The majority of Rohingya that come to Bangladesh since August 2017 are mostly from either Maungdaw or Buthidaung Township in Northern Rakhine State. Most of the people in the Maungdaw Township dwell in various villages along or near the riverbanks or coastline near Myanmar-Bangladesh border (The Asia Foundation 2020). This region experiences major cyclones on average once every three years, and regularly experiences landslides, flash floods, and heavy monsoons.

Cyclones Giri in 2010 and Komen in 2015 both had direct hits on Rakhine state and devastated most of the coastal regions including the capital city of Sitwe (Rochanakorn 2015; UN OCHA 2013). In the aftermath of Giri the crucial port city of Kyaukphyu was covered in about 5 feet of water and it has been reported that every building was either destroyed or significantly damaged. Numerous coastal villages were completely destroyed and many were severely damaged. Approximately, 15,000 homes were destroyed in Rakhine State. The Red Cross estimation however shows that approximately 1.1 million people were affected by the storm and about 100,000 people were left homeless. Electrical power was wiped out in urban areas and was not fixed for a considerable period of time. Giri, which hit during harvest time, along with subsequent flooding and rain from a worse than normal monsoon season destroyed 1.7 million tons of rice in the State. Also, the heavy precipitation led to a particularly bad malaria season which affected the most vulnerable members of the population (Bandur 2018). These climate shocks interacted with significant economic and social crises already occurring in the state and destroyed marginal livelihoods of thousands of local Rohingya. Also, the ethnic violence in 2012 could be traced directly to the impacts of Cyclone Giri.

Controversy developed in the immediate aftermath of Cyclone Giri as local residents and the international community complained that the Burmese government did not provide adequate disaster warning to the regions. Later it was found that the government had evacuated much of the cities of Sitwe and Kyaukphyu, but resentment lingered especially among residents in other communities. This resentment led to a number of conspiracy theories about the government and a general sense that Rakhine Buddhists would have to take care of themselves in the future. Local politicians adopted strongly pro-Buddhist stances and local Buddhist militias grew in numbers and ultimately played a significant role in the events of 2017.

Cyclone Komen in 2015 was generally a weaker storm. Since it was a slow-moving cyclone, Komen brought tremendous amount of torrential rain and flooding to the region. It destroyed over 500,000 homes and destroyed huge areas of crops. It particularly affected the Rohingya population as many were still displaced by Cyclone Giri and previous ethnic violence. Many of the internally displaced camps had to be forcefully evacuated by the military as the Rohingya were reluctant to leave as they did not trust the authorities. Ultimately most left the camps, which were destroyed by the storm. This necessitated the hasty building of new camps for internally displaced peoples. These climatic events led to increased social and economic pressures in Rakhine State as well as an increase in military presence in the area. To give a sense of how Cyclone Komen affected the region, consider the fact that Rakhine State actually had a relatively low out-migration rate before the cyclone, but by 2016, even before the ethnic cleansing, approximately 10,000 people were leaving the state each month.

\section{The multifaceted nature of current sustainability challenges}

Rapid population influx because of any forms of forced migration can cause cyclical and chronic environmental damage that can be difficult to manage or contain. The impacts of refugees on their environment attest to their desperation and need, and the Rohingya refugee crisis is no exception. Currently, the Rohingya are entangled (as both cause and victim) in multifaceted and severe sustainability challenges. Sudden influx of almost a million Rohingya caused severe deforestation in southeast Bangladesh. Eventually, this scale of environmental destruction has increased Rohingya's exposure to disasters, such as flashfloods, and landslides.

Usually, southeast Bangladesh experience severe monsoons each year. Also, the region falls on the path of tropical 
Fig. 1 Rohingya Camp (Kutupalong, Cox's Bazar, Bangladesh)

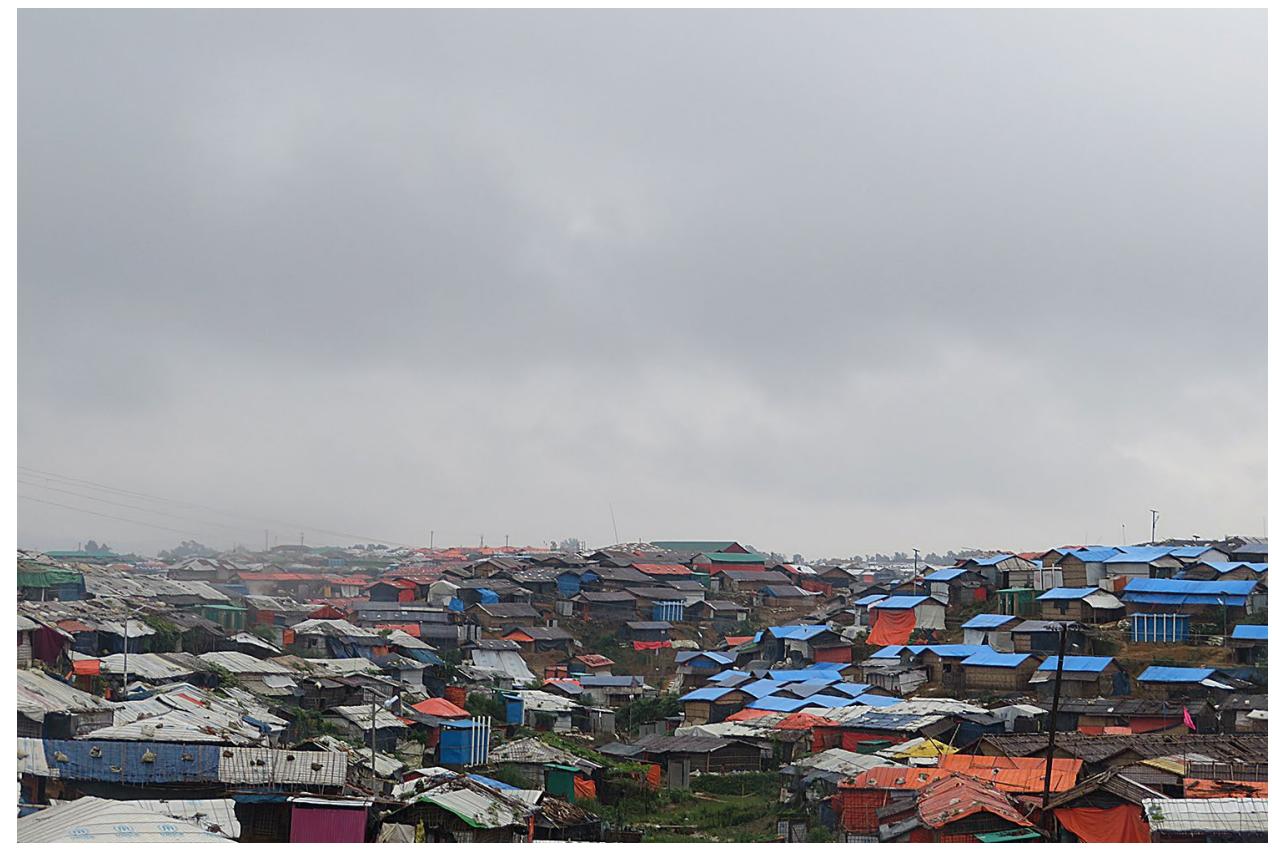

cyclones that originate in the Bay of Bengal. It is now apparent that even though the Rohingya could escape the ethnic violence in Myanmar, they are now facing various environmental hazards in Bangladesh. The sustainability challenges became more complicated and complex, since the entire refugee camp have exposed to the on-going global pandemic. Further details are as follows:

\section{Deforestation and habitat loss in southeastern Bangladesh}

Deforestation and loss of natural habitat in the refugee receiving area are mostly the result of needing to build impromptu housing and shelter as well as for cooking fires (Huq 2018). The damage and scale of deforestation in the southeast border of Bangladesh is quite significant (Fig. 1).

Deforestation can cause a plethora of negative effects. These include the furthering of adverse environmental impacts, including a decrease in resource availability and diminished habitats for local plants and animal species. Each of those consequences has cyclical impacts that feed into one another and perpetuate further negative outcomes. In the case of habitat loss, plant and animal species are forced to adapt to new environmental factors or be lost. Deforestation also increases soil erosion and landslides (Biswas and Tortajada 1996). As a result, both native species and the local populations are greatly affected by deforestation. Of course, this can, as it has in the Rohingya situation, exacerbate tensions between the local host and Rohingya communities (UNDP 2018).
Prior to the large exodus of Rohingya, the region near Myanmar-Bangladesh border in Cox's Bazar district was largely forested with only some cultivable land. In a oneyear period between December 2016 and December 2017, the land occupied by refugee settlements in Kutupalong extended from 146 to 1365 hectares, with a total astounding growth rate of 835 percent (Hassan et al. 2018).

Deforestation has also impacted local residents, who depended on local forest resources for their livelihoods. By continuing to take resources from the land and not giving the environment time to replenish, numerous long-term impacts can negatively affect Rohingya as well as the host communities.

As deforestation increases, the regularity and number of hazardous situations also increases. The removal of groundcover, such as low-growing grasses and various shrubs, combined with the extensive harvesting of wood from these areas, leads to extensive soil erosion (UN Environment Programme 2018). It is especially the removal of topsoil, which in turn creates less fertile, viable soil for growing crops and re-growing trees and forest groundcover (Hassan 2018). In the region, the effects of deforestation are much worse during the monsoons season. Every year, starting around May and lasting until September, the Rohingya camps of Cox's Bazar in Bangladesh brace for the impact of monsoon season. Annual average rainfall in Cox's Bazar is $3770 \mathrm{~mm}$ (UNDP 2018), which is the second highest in the country. This rainfall causes large-scale flashfloods and landslides.

The threat from monsoons is compounded in the camps with a high number of people packed into confined shelters that are poorly outfitted against severe weather. Cox's Bazar is particularly vulnerable due to its location along the 
low-lying coast of Bangladesh, which is highly susceptible to cyclones and storm surges (ACAPS 2018). The potential for damage in the camps has been made higher due to the cutting away of trees and hillsides to make room for shelters. This has produced an area both geographically vulnerable to monsoons and built with an increased risk of landslides, flash floods and mortality (UNDP 2018).

The heavy rain, wind, and violent storms has led to landslides, and flashfloods and regularly destroy thousands of temporary makeshift homes. In just one week in 2019 monsoon-related events affected more than 28,000 Rohingya. And in the entire monsoon season more than 80,000 Rohingya were directly affected and almost 17,000 of them were temporarily displaced (ISCG 2019).

With the high risk of damage from severe weather and with the higher potential for flashfloods and landslides, there is an inherent risk of water pollution, water-borne diseases, and transportation blockages during and following severe weather events. The Rohingya already face limited access to medical care and resources, and increases in illnesses can put further strain on transportation for emergency aid.

Also, human-elephant conflicts are increasingly common in the area. Prior to the massive influx of Rohingya in 2017, the Kutupalong camp was designated for the habitat of endangered Bangladeshi Asian elephant (UN Environment Programme 2018). There have been eleven deaths and numerous injuries among the Rohingya because of their encounters with local wild elephants. However, in the past two years several groups in the camps have created lookout towers to warn of elephants approaching and a system of noises to dissuade elephants from crossing through inhabited areas. Plans are even underway to create a wide path through the camps to restore the elephants' traditional migratory paths.

\section{Inter-annual climate variability in the area}

The climate in Bangladesh is highly sensitive to inter-annual climate variability and change driven by El Niño-Southern Oscillation (ENSO). ENSO is an irregularly periodic variation in winds and sea surface temperatures over the tropical eastern Pacific Ocean, affecting the climate of much of the tropics and subtropics. In short, the warming phase of the sea temperature is known as El Niño and the cooling phase as La Niña. Previous studies by Chowdhury (2003) showed that the climate in Bangladesh-despite weak quantitative correspondence between the strength of ENSO and the rainfall anomaly - has a particularly strong relation with the Southern Oscillation Index (SOI) extremes: negative SOIs (El Niño) for dry, and positive SOIs (La Niña) for wet. Therefore, El Niño brings drought or drier than normal weather (e.g., 1983, 1997, and 2015) while La Niña brings floods or wetter than normal weather (e.g., 1988, 1998, and 2017) for Bangladesh.

Droughts during an El Niño year may be interrupted by devastating cyclones, as occurred on April 29-30, 1991, which killed 150,000 people. The recent tropical cyclone Fani (May 3, 2019), which was the strongest storm in 20 years to make landfall in India, is also another example. Drought conditions can also lead to devastating forest and grassland fires on barren areas, which threaten biodiversity, wildlife, and livelihoods. There is also evidence that drought or El Niño is associated with a heightened risk of certain vector-borne diseases (e.g., mosquito-born, water-borne, and rodent-borne) in Bangladesh. This is particularly true for malaria, but associations are also suggested with respect to epidemics of other mosquito-borne and rodent-borne diseases that can be triggered by El Niño weather conditions. It has already been reported in national dailies that, with the arrival of summer in 2019, the number of diarrhea patients in and around the capital Dhaka has gone up steeply. While this rise in diarrhea cases can be attributed to consumption of unsafe water and food, the on-going El Niño, which caused higher temperatures during the summer, is partly responsible for this disease outbreak.

The greatest El Niño-related threat to trees and forests is that of fire. Forest fires in the landscape of Bangladesh, particularly the barren hills in Cox's Bazar, are common, even without El Niño. The fires affect climate and the smoke causes serious harm to peoples' health especially potentially life-threatening respiratory problems. For instance, in 2019 a fire gutted 30 houses and a mosque in Cox's Bazar's Kutupalong Rohingya camp. Two Rohingyas were injured while trying to douse the fire. Luckily no major damage was reported due to the fire, but the Rohingya Camp in Cox's Bazar is particularly fire sensitive during any El Niño year. ENSO can also further complicate the Rohingya Crisis by increasing security issues in the country. Drought caused by El Niño may lead to local scarcity and increased resource competition, especially over freshwater. Despite some dissenting views, the emerging consensus is that water scarcity is significantly correlated with armed conflict around the globe. $^{2}$

\footnotetext{
${ }^{2}$ For instance, civil conflicts in the tropics double during warm or dry or drought (El Niño) years relative to normal or cold or flood ( $\mathrm{La}$ Ninã) years. While historians have argued that El Niño (and La Ninã) may have driven global patterns of civil conflict in the distant past, there are studies (Solomon et al. 2011 and references) directly associated planetary-scale climate changes with global patterns of civil conflict. This result, which indicated that El Niño (and La Ninã) may have had a role in $21 \%$ of all civil conflicts since 1950, is the first demonstration that the stability of modern societies is strongly related to the global climate. There are also recent studies that show links between El Niño-related drought and recent conflict in Syria (Kelley et al. 2015). Severe droughts can cause displacement and potentially conflict, particularly in agrarian societies in Syria which is strongly dependent on rainfall. Bangladesh also had serious civil conflicts and
} 
Chances of conflicts can be heightened, since the Rohingya in southeast Bangladesh are at imminent risk of El Niño-related drought or La Niña-related flooding now or anytime in the foreseeable future. Their hand-built tarpaulin and bamboo shelters are threatened by strong winds and cyclones, and heavy rainfall during the monsoon season. These ENSO-related droughts, fires, cyclones, and flooding can cause displacement, dissatisfaction, and, potentially, conflict, particularly in the barren hills of Cox's Bazar where the Rohingyas are strongly dependent on water and most susceptible to landslides and other adverse events.

\section{The global pandemic has complicated the overall scenario}

The presence of the COVID-19 pandemic has exacerbated the daily struggle in Rohingya camps as testing has proved to be a challenge (UNHCR 2020). Here, physical distancing is nearly impossible, since the population density in Rohingya camps is astronomically high (Alam 2020). On average, it is 40,000 inhabitants per square kilometers, while in some places, it is over 70,000 (Assessment Capacities Project 2020). In addition, there is a major lack of awareness about COVID among Rohingya (Ahmed 2020).

Currently, fewer humanitarian workers are on the ground to provide services to refugee populations (Spoerri et al. 2020). These conditions have exacerbated the pre-existing acute shortage of health facilities in refugee camps. In the refugee camps in Bangladesh, on average, four to five Rohingya (including children) stay in a single temporary makeshift room which is often made of tarpaulin sheets and bamboo sticks (Ahmed 2020). Their floors, where they sleep on plastic clothes or papers, are usually muddy in the rainy season (Islam and Nuzhath 2018). In such conditions, the COVID-19 pandemic or any other public health crises can have a far-reaching impact (PQMD 2020). In refugee contexts, a high-scale outbreak is possible even with low rates of transmission (Truelove et al. 2020). Therefore, any unequal response to the COVID-19 situation at refugee camps may bring unimaginable causalities and can put the health of both the refugees and host communities at stake.

In response, the UNHCR and the Bangladeshi government have taken extreme steps to stop or delay transmission of the disease in the camps. Most notably, entrance into the camps has been forbidden for all organizations except those providing essential services. These initiatives have also limited the movement of refugees outside of the camps.

\section{Footnote 2 (continued)}

political unrest during the El Niño years in 1970-1972, 1982-1983, 1991, and 2013-2014.
However, these measures have put an almost complete halt to organizations doing educational programming, as well as gender-based violence training and peacebuilding initiatives. Even though some of these initiatives are gradually recommencing after a pause during the peak of the pandemic, lack of opportunities and services have further isolated the Rohingya from the host communities, which will probably lead to increased distrust, suspicion, or hate between the two groups.

The long-term impacts of COVID-19 are still evolving (Lichfield 2020). During this pandemic, people have experienced dysfunctional health systems and inefficient government responses (Okoi and Bwawa 2020; Shammi, BodrudDoza, Islam, \& Rahman, 2020). However, the world has limited knowledge on the potential risks and impacts of the global pandemic on the refugees and displaced populations (Sen 2020). These populations often are forced to live with very limited resources in densely populated situations provided by either the host countries or the international aid and humanitarian agencies (Efrat 2006; Lau, Samari, Moresky, Casey, Kachur, Roberts, \& Zard, 2020). Therefore, it is not surprising that refugees like Rohingya in Bangladesh will likely be victims of further marginalization, exploitation, hate crimes, and xenophobia during and after the COVID-19 pandemic (Abrar 2020).

\section{Sustainability-peace nexus in Rohingya context}

Solutions to the Rohingya crisis are usually envisioned in macro-terms with what we believe has been an overemphasis on those solutions grounded in state-centric, neoliberal, and accountability paradigms. While economic development and accountability are important steps, it must be kept in mind that neither will greatly improve the situation on the ground for the average Rohingya in Cox's Bazar.

Solutions offered to the crisis as well as to impending climate change in the region have overwhelmingly been rooted in state-centric paradigms. First of all, the crisis has been navigated from its beginning as a political tug of war between Myanmar and Bangladesh. Of course, each country has its own interests, which only aligned briefly with the interests of the Rohingya. For example, the government of Bangladesh used the crisis to build popular national and international supports initially as a symbolic form of hospitality to fellow Muslims.

And since China has significant geopolitical and economic interests in the region, it has taken an active but cautionary mediating role in negotiations. However, the Chinese or Indian response did not help either Bangladesh or Rohingya in the efforts for Rohingya repatriation. During the 48th meeting of the 75th United Nations General 
Assembly session, a proposal (A/C.3/75/L.34) regarding the Rohingya issue and other human rights situations in Myanmar were considered. China and Russia took stance in favor of Myanmar, while India abstained from voting (The Daily Star 2020; UNGA 2020).

With the interests of each country outweighing their interests in the Rohingya, it is hard to imagine a sustainable solution arising at that macro-level. Each country in the region is focused on pursuing economic development especially by courting larger economic powers and attempting to open up trade routes for resources and goods. For example, Bangladesh is struggling to provide support and services to almost a million Rohingya, albeit with the help of various UN and other humanitarian organizations. The Bangladesh government might explore options for demanding financial compensation from Myanmar, since the Rohingya crisis created gigantic social and environmental burdens on Bangladesh (Hammer and Ahmed 2020).

Similarly, attempts to ameliorate climate change in the Bay of Bengal area suffer from the same state-centered ethos. Countries in the region, when they do discuss climate change, push almost solely on burden sharing from countries that have contributed more to climate change such as India and China, but they cannot push too hard on these countries as they depend on them for economic development or for other political alignments. Some scholars and UN personnel have proposed sub-regional solutions to climate change, for instance, by creating a Bay of Bengal coalition of countries or by having ASEAN play an active role in climate change or humanitarianism crises (Chaturvedi and Sakhuja 2015). However, in both cases, these efforts will be stymied by state sovereignty and national interests. We fear that any initiative that gives more responsibility to states also further enhances state power and autonomy, thus increasing their power over ethnic minorities such as the Rohingya. Instead, we propose that more emphasis should be placed on local actions and empowerment of the Rohingya and other affected communities, more particularly, by decolonizing Rohingya solutions.

\section{Decolonizing Rohingya solutions}

Here, we follow recent scholarship on decolonization that calls for "minority groups [to] create alternatives to liberal institutions embodied by the states" (Álvarez and Coolsaet 2018). Such decolonization should be the foundation for positive peace among the Rohingya and should be supplemented by the local knowledge of the host communities in Bangladesh for bringing about significant improvements in the sustainability-peace nexus in the region.

The roots of the Rohingya crisis are grounded in the "Othering of the Rohingya", something that is done in varying degrees by all governments in the region. Without some forms of subjectification, where the Rohingya are able to claim their rights to identify themselves and their rights (Simmons 2011, chapter 5), they will continue to be branded as inferior by dominant classes, particularly, by the local Buddhist majority in Rakhine State. However, considering this cauterization has been taking place for decades and there are very few natural allies in the region, we are not sanguine about a reversal of this Othering process any time soon. Such local activism could bring about empowerment and improve socio-economic conditions.

In Myanmar, Rohingya have been stateless for almost four decades and this disempowerment has exacerbated all sorts of issues among the Rohingya including gender-based violence, segregation of women, and potentials for extremism. Local activism though could reverse trends among international actors that have been making decisions on behalf of the Rohingya with little input from them, including decisions about repatriation, relocation, and bringing of a case to the ICC.

The first step in this decolonization should happen by privileging local knowledge held by the Rohingya, which is the cornerstone of locally relevant sustainability and peacebuilding measures. Currently, Rohingya are seen by the vast majority of the humanitarian aid and human rights communities as victims that need handouts. There have been few attempts to learn from the Rohingya (for an exception, see the work of the NGO Artolution). This is a prime example of what has been called epistemic injustice or what Santos (2015) calls epistemicide, knowledge, experiences, and insights from the Rohingya need to be tapped and respected, so that they can be seen as full or even privileged participants in any discussions of repatriation and relocation.

Yes, they have suffered decades of persecution punctuated by the enormous human rights abuses of 2017 and 2018, but the Rohingya are also survivors that have endured decades of statelessness and persecution by developing coping mechanisms that are little known outside of their community (Cf. Simmons 2019, chapter 7). Even their coping mechanisms are often portrayed as further victimizations. For instance, Rohingya migration and smuggling to a number of countries in the region are reported as ways that the Rohingya are victimized and rarely as forms of adaptation to decades of persecution. Indeed, they are too often conflated with human trafficking, which admittedly is a problem, but which further reinforces the Rohingya's victim status.

To privilege the Rohingya's voice and their knowledge it will be critical to become conscious of how deeply embedded particular knowledge systems are in the modern liberal systems. In this case, technical solutions based upon the liberal subject have dominated development, humanitarian, and climate change discourses. While such solutions provide much needed reliefs especially at the height of the refugee crisis, long-term solutions, which 
should ensure the nexus between sustainability and peace, will need to involve a new way of thinking, and we propose that it be rooted in the Rohingya's worldviews.

We are cognizant that the Rohingya as a group have been reified, both as a social identity and in time. There is little sense that Rohingya culture is dynamic and has evolved in very specific ways because of their decades of persecution. Also, it is assumed that all Rohingya share the same values and want the same things. While that may be true in terms of survival, they are not a hegemonic group. Instead, they come from different parts of Myanmar and have different ideas of what the future should hold. In addition, though they are often referred to as Rohingya Muslims, the group includes groups of Hindus and Christians, and there are conflicts between the religious groups that manifested themselves in Myanmar and more recently in the Bangladeshi refugee camps.

Since the Rohingya have been defined for so long by their persecution, it may take time to unpack their beliefs about land, property, community, sustainability, peace, and other pivotal issues. And since the Rohingya have a strong oral tradition through storytelling, music, and songs, it will take a critical ethnographic perspective to better understand their world view (Simmons and Feldman 2018). Some NGOs such as Artolution are doing important work in identifying dozens of Rohingya artists and having them mentor young Rohingya in traditional art forms. Murals done by Rohingya children led by Rohingya mentors now pepper the camps. Increasingly, Rohingya artists, including traditional musicians, are appearing on social media channels like Facebook and Twitter. Hopefully, these efforts might lead to a renewal and appreciation of Rohingya culture and knowledge. When incorporated into positive peacebuilding programs as is being done by Artolution, they could lead to significant advances in the peace-sustainability nexus.

From the scant evidence available, it is safe to assume that the Rohingya's culture is closer to indigenous groups in the Americas: "These communities are not fighting for the "distribution of risks and impacts," but for the right to live "in relation to one another and the natural world in non-dominating and nonexploitative terms" (Coulthard 2014: 13) than the development model grounded in foreign direct investment that has led to their displacement. Of course, we are cognizant that many attempts at tapping into indigenous knowledge have ended up coopting that knowledge to advance the western development agenda (Coulthard 2014) and that such efforts often further empowering elites among a marginalized group thus making the more vulnerable community members (often women) even more vulnerable (Williams and Mawdsley 2006).

\section{Context-specific strategies to promote sustainability-peace nexus}

To ensure sustainability and peace, it is important to think both short- and long-term initiatives that can help the entire Rohingya population to enjoy a dignified and meaningful life in a sustainable manner. Some of the suggestions are as follows:

First, legal refugee status should be given to the Rohingya population, who are currently living in Bangladesh. (ISCG, 2019), which will grant them better civil and humanitarian protections and allow them to have access to necessary resources and services. The government of Bangladesh currently refers to the Rohingya that arrived in 2017 and after as "Forcibly Displaced Myanmar Nationals" (FDMNs), while the UN refers them as 'Refugees,' although not all the Rohingya population would meet the criteria for legal refugee status (IOM, ISCG, UN RC Bangladesh 2019).

It is also important for the Bangladesh government to refocus their warranted frustration with the situation away from the Rohingya population and back towards the Myanmar government. The Bangladesh government should refocus their perspective on the political cause of the Rohingya crisis and enhanced diplomacy to resolve it. A key first step in resolving the crisis should come from international organizations, such as the United Nations by pressuring Myanmar for reaching some preliminary agreements on basic legal questions such as regarding safe and dignified Rohingya repatriation with Burmese citizenship.

Second, natural disaster preparedness and response should be understood in a more comprehensive way by involving inter-sectoral coordination, information sharing, and monitoring and evaluations, and adaptive learning (ISCG 2019). Currently, it is under the umbrella of many other sectors. With more commitment to natural disaster preparedness as its own entity, it will be effective in working in tandem instead of working through the other sectors. In this process of natural disaster preparedness and response, it is also important to include Rohingya and host community. Inclusive and coordinated disaster preparedness and response can mitigate the level of crisis in substantial manner.

Third, most of the Rohingya are still living in initial emergency shelters. The majority of the population is still living under tarps which offer little-to-no protection from the extreme winds and rain that are likely to occur during the monsoon season. The emergency shelters are a functional short-term solution but transitioning towards long-term solutions will need to include increasing bamboo treatment plants and more durable shelter designs. Moreover, the access refugees have to temporary collective 
shelters in the camps in case of emergencies such as flooding and heavy rain, are non-existent. Since there are no cyclone shelters in the camps, the Rohingya remain even more vulnerable during intense cyclones. Long-term, looking into the construction of sturdy, reliable cyclone or disaster shelters would provide safe and consistent protection from weather related events.

From the very beginning, the Government of Bangladesh and UN agencies have worked relentlessly to train local volunteers and NGO workers to prepare for a myriad of emergencies. The emergency response plans and drills for evacuations and distribution of supplies need to be maintained and expanded upon to increase the number of people they can reach in the time frame they have. The 72-h max delivery time for supplies and the prepositioning of supplies also can be considered a success but still could use improvement (ISCG 2019). The effect of landslides, floods and other common natural disasters in the region can impact infrastructure such as roads, communication, and accessibility and hinder distribution plans. In the short term, having more supplies readily available in the camps or closer to the camp sites would allow for a quicker response time and less distance to be covered in case of emergencies. Also, increasing the number of prepositioned supplies to account for the larger number of refugees would be possible with more funding allocated to this initiative. Other benefits of current procedures shown in other sectors, but influencing natural disaster preparedness, are certainly important to keep up with.

Fourth, it is important to explore ways to decrease dependency on humanitarian aid and other supports. Rohingya skills should be nurtured so that they get the opportunities to develop their own livelihood activities. Also, whatever the decisions are made by the Governments of Bangladesh and Myanmar or international organizations for their wellbeing, Rohingya should be part of all decisions and interventions that might directly or indirectly affect them.

Finally, the Bangladesh government and other development partners need to explore creative ways to include local faith leaders in their efforts to crisis management, and to achieve development and sustainability in local context. Faith leaders play as the vectors of information dissemination and community engagement, particularly in resourceconstrained crisis situations. They can also work along with humanitarian agencies on mental health and wellbeing issues (UN OCHA 2020). Faith leaders have tremendous influence among their followers (Uddin 2020), and among the non-followers, they have certain level of social acceptance. Among the Muslim-dominant, conservative Rohingya, conducting awareness sessions and training for the faith leaders is essential to scale up community alertness on pandemic or other forms of crisis response. The faith leaders can use Quranic teaching and Prophet Mohammed (SWAS)'s historic Hadith or narration. One, among many others, for example:
"When you hear that a plague is in a land, do not enter it and if the plague breaks out in a place while you are in it, do not leave that place." Prophet Muhammad (SWAS) narration (cited from Uqba, 2020).

\section{Conclusion}

Southeast Bangladesh is one of the most least developed, mountainous, and disaster-prone regions in the country. Prior to the Rohingya influx of 2017, people in the region experienced numerous sustainability- and peace-related challenges. In recent decades, the region has struggled to maintain negative peace and the Rohingya crisis has made the situation even more complex, not only for the host communities, but also for the incoming Rohingya.

However, it is not very clear that how much the environment for positive peace exists to support sustainability-peace nexus in the Rohingya camps, since some parts of their peace components depends on their repatriation, safety, and security in Myanmar. The Rohingya suffer from a range of geopolitical and neocolonial forces.

The situation is further exacerbated by climate stresses. The entire region of the Bay of Bengal especially Rakhine State in Myanmar and Cox's Bazar in Bangladesh are projected to be the hardest hit areas in Asia by climate change in the next few decades. In recent years, the majority of the tropical cyclones that made landfalls in Bangladesh were in this area and current IPCC projections suggest that the region will experience increasing intensity and frequency with tropical cyclones (IPCC 2014).

The Rohingya have escaped from ethnic violence in their home country Myanmar, but are trapped in environmental risks and vulnerability in Bangladesh. However, the sustainability-peace nexus for the Rohingya not only depend on their exposure to local environment and global environmental change, but also geopolitical factors, where number of large states are involved with their high stakes of interests and priorities.

The Rohingya were never at the center of solutions that affect their lives, livelihoods, and wellbeing. In most cases, they were always either victims or passive recipients of decisions or interventions. In this paper, we argue that despite their locations either in Myanmar or in Bangladesh, Rohingya knowledge, insights, and experiences should be acknowledged and integrated into any development interventions that directly affect them. State-led or expert-led interventions are necessary; however, it is equally important to know that excluding Rohingya from any decisions or interventions can only worsen the situation in the long-run. Therefore, this paper argues that critical issues in the sustainability-peace nexus for Rohingya can only be achieved by decolonizing available solutions. Both Myanmar and 
Bangladesh should work closely with various other national and international agencies and make sure that Rohingya are not only the passive recipients of benefits or any other decisions or interventions, but also critical agents of change for long-term sustainability and peace.

Acknowledgements The authors would like to acknowledge Robin Alhaddad, Pradipto Vaskar Rakshit and Md. Zahidur Rahman for their invaluable support during field research. They also acknowledge three anonymous reviewers and editors for their insightful comments and suggestions for strengthening the paper.

\section{References}

Abrahams D (2019) From discourse to policy: US policy communities' perceptions of and approaches to climate change and security. ConflSecur Dev 19(4):323-345

Abrar CR (2020) COVID-19 and the Rohingya: Hunger, exploitation, hate crimes and xenophobia. The Daily Star (July 14, 2020). https://www.thedailystar.net/opinion/news/covid-19-and-the-rohin gya-hunger-exploitation-hate-crimes-and-xenophobia-1929817

ACAPS (2018) Thematic Report-April 2018—Rohingya Crisis: lessons learned about the impact of cyclones. https://reliefweb.int/ report/bangladesh/thematic-report-april-2018-rohingya-crisislessons-learned-about-impact-cyclones

Ahmed S (2020) Coronavirus closes in on Rohingya refugees in Bangladesh's cramped, unprepared camps. The conversation. https:// theconversation.com/coronavirus-closes-in-on-rohingya-refugeesin-bangladeshs-cramped-unprepared-camps- 135147

Ahmed T, Alam J (2017) 26 dead after boats carrying fleeing Rohingya sink in Bangladesh. https://www.latimes.com/nation/ct-bangl adesh-boat-sinks-20170831-story.html

Alam J (2020) Rohingya refugees brace for potential coronavirus outbreak. Available via The Diplomat. https://thediplomat.com/2020/ 04/rohingya-refugees-brace-for-potential-coronavirus-outbreak/

Álvarez L, Coolsaet B (2018) Decolonizing Environmental Justice Studies: a Latin American perspective. Capit Nat Sociali 1-20

Amadei B (2019) Engineering for peace and diplomacy. Sustainability. https://doi.org/10.3390/su11205646

Assessment Capacities Project (2020) COVID-19 Rohingya Response. https://reliefweb.int/sites/reliefweb.int/files/resources/20200319 acaps_covid19_risk_report_rohingya_response.pdf

Bandur M (2018) Climate justice in the Rohingya crisis. TECSEA Admin. August 6. https://www.tecsea.info/blog/climate-justicein-the-rohingya-crisis

Barnett J, Adger WN (2007) Climate change, human security and violent conflict. PolitGeogr 26(6):639-655

Berkes F, Folke C (1998) Linking social and ecological systems: management practices and social mechanisms for building resilience. Cambridge University Press, New York

Biswas AK, Tortajada C (1996) Environmental Impacts of the Rwandan refugees on Zaire. Ambio J Hum Environ 25(6):403-408

Brauch HGN, Oswald U, Grin J, Scheffran JR (2016) Handbook on sustainability transition and sustainable peace. Springer, Switzerland

Chaturvedi S, Sakhuja V (2015) Climate change and the Bay of Bengal: evolving geographies of fear and hope. ISEAS Pub, Singapore

Cheung S (2011) Migration control and the solutions impasse in south and southeast Asia: implications from the Rohingya experience. Inter Aff 25(1):50-70

Chowdhury R (2003) The El Niño-southern oscillation (ENSO) and stream-flows in the greater ganges-brahmaputra-meghna (GBM) basins - a climate outlook. In: Mitra AP, Sharma C (eds) Global environmental changes in south asia: a regional perspective. Springer, Dordrecht, pp 258-270

Coulthard GS (2014) Red skin, white masks: rejecting the colonial politics of recognition. University of Minnesota Press, Minneapolis

Downing AS, Spijkers J, Norstrom A, Preiser R (2020) Resilience and sustainable peace: managing climate related security \& development risks in the anthropocene. Global resilience partnership. http://www.globalresiliencepartnership.org/wp-content/uploads/ 2020/04/Resilience-and-Sustainable-Peace_GRP_GRAID_Backg round-Paper-2020-002.pdf

Efrat E (2006) The west bank and gaza strip. Routledge, New York

Galtung J (1969) Violence, peace, and peace research. J Peace Res 6(3):167-191

Hassan MM, Smith AC, Walker K, Rahman MK, Southworth J (2018) Rohingya refugee crisis and forest cover change in teknaf, Bangladesh. Remote Sen 10(5):689. https://doi.org/10.3390/rs10050689

Human Rights Watch (2019) Bangladesh: clampdown on Rohingya refugees. https://www.hrw.org/news/2019/09/07/bangladeshclampdown-rohingya-refugees\#. 7 Sept 2019

Huq S (2018) Tackling the environmental challenges in Cox's Bazar. The Daily Star (Feb 07, 2018). https://www.thedailystar.net/opini on/politics-climate-change/tackling-the-environmental-chall enges-coxs-bazar-1530940

International Crisis Group (2019). A sustainable policy for Rohingya refugees in Bangladesh. Brussels, International Crisis Group. https://www.crisisgroup.org/asia/south-asia/bangladesh/303-susta inable-policy-rohingya-refugees-bangladesh

InterSector Coordination Group (2019) ISCG situation report Rohingya refugees crisis, Cox's Bazar. January

IOM, ISCG, UN RC Bangladesh (2019) 2019 Joint response plan for Rohingya humanitarian crisis. https://reliefweb.int/report/bangl adesh/2019-joint-response-plan-rohingya-humanitarian-crisisjanuary-december-enbn

IPCC (2014) Climate change 2014: impacts, adaptation, and vulnerability. Part A: Global and sectoral aspects. Contribution of Working Group II to the Fifth Assessment Report of the Intergovernmental Panel on Climate Change. Cambridge University Press, Cambridge

IPCC (2018) Summary for policymakers. In: Masson-Delmotte V, Zhai P, Pörtner HO, Roberts D, Skea J, Shukla P R, Pirani A, Moufouma-Okia W, Péan C, Pidcock R, Connors S, Matthews JBR, Chen Y, Zhou X, Gomis MI, Lonnoy E, Maycock T, Tignor $\mathrm{M}$, and Waterfield T (eds.) Global Warming of $1.5^{\circ} \mathrm{C}$. An IPCC Special Report on the impacts of global warming of $1.5^{\circ} \mathrm{C}$ above pre-industrial levels and related global greenhouse gas emission pathways, in the context of strengthening the global response to the threat of climate change, sustainable development, and efforts to eradicate poverty. https://www.ipcc.ch/sr15/download/\#full. Accessed 20 Aug 2020

ISCG (2019) ISCG monsoon response in Rohingya refugee camps weekly update. https://reliefweb.int/report/bangladesh/iscg-monso on-response-rohingya-refugee-camps-weekly-update-6-12-septe mber-2019. 6-12 Sept 2019

Islam MM, Nuzhath T (2018) Health risks of Rohingya refugee population in Bangladesh: a call for global attention. J Glob Health 8(2):020309. https://doi.org/10.7189/jogh.08.020309

Kashyap A (2013) Burma's bluff on the two-child policy for Rohingyas. https://www.hrw.org/news/2013/06/21/burmas-bluff-two-childpolicy-rohingyas

Koubi V (2019) Climate change and conflict. Annu Rev PolitSci 22(1):343-360

Larmer B (2017) Without a home, and without hope. https://www. nationalgeographic.com/photography/proof/2017/08/rohingyarefugees-myanmar-bangladesh/

Lau LS, Samari G, Moresky RT, Casey SE, Kachur SP, Roberts LF, Zard M (2020) COVID-19 in humanitarian settings and lessons 
learned from past epidemics. Nat Med. https://doi.org/10.1038/ s41591-020-0851-2

Leonard H, Ahmed S (2020) Environmental responsibility and Rohingya refugees: potential grounds for justice. Local Env 25(11-12):1021-1031

Lewis S (2017) By land, river and sea, Rohingya make their escape from Myanmar. https://www.reuters.com/article/us-myanmarrohingya-exodus-idUSKCN1BH1IW

Lichfield, G. (2020) We're not going back to normal. MIT Technology Review. https://www.technologyreview.com/2020/03/17/905264/ coronavirus-pandemic-social-distancing-18-months/

Niesenbaum R (2020) Sustainable solutions: problem solving for current and future generations. Oxford University Press, Oxford

Okai O, Bwawa T (2020) How health inequality affect responses to the COVID-19 pandemic in sub-Saharan Africa. World Dev $135: 105067$

PQMD (2020) COVID-19 identified in Rohingya refugee camp. Annapolis, MD: partnerships for quality medical donations. http:// www.pqmd.org/covid-19-identified-in-rohingya-refugee-camp/

Raleigh C (2010) Political marginalization, climate change, and conflict in African sahel states. Int Stud Rev 12:69-86

Rochanakorn K (2015) More than one month after Cyclone Komen, some impacted people remain homeless. https://www.unhcr.org/ en-us/news/latest/2015/9/55ffd4c56/month-cyclone-komen-impac ted-people-remain-homeless.html

Santos de Sousa B (2015) Epistemologies of the South: justice against epistemicide. Routledge, Abingdon

Schleussner C-F, Donges JF, Donner RV, Schellnhuber HJ (2016) Armed-conflict risks enhanced by climate-related disasters in ethnically fractionalized countries. PNAS 113(33):9216-9221

Sen S (2020) The pandemic under siege: a view from the Gaza Strip. World Dev 135:105063

Shammi M, Bodrud-Doza M, Islam ARM, Rahman MM (2020) COVID-19 pandemic, socioeconomic crisis and human stress in resource-limited setting: a case from Bangladesh. Heliyon 6(5):e04063. https://doi.org/10.1016/j.heliyon.2020.e04063

Simmons WP (2011) Human rights law and the marginalized other. Cambridge University Press, Cambridge

Simmons WP (2019) Joyful human rights. University of Pennsylvania Press, Philadelphia

Simmons WP, Feldman LR (2018) Critical ethnography and human rights research. In: Smith R, McConnel L (eds) Research methods in human rights. Routledge, New York

Soi C (2019) Can local and faith leaders help halt the spread of Ebola in DRC? Aljazeera news. https://www.aljazeera.com/news/2019/ 11/local-faith-leaders-halt-spread-ebola-drc-191117111929385. htm. 17 Nov 2019

Spoerri M, Ullah Y, Nwangwu NC (2020) The Rohingya and COVID19: towards an inclusive and sustainable policy response. Independent diplomat. https://reliefweb.int/sites/reliefweb.int/files/ resources/The\%20Rohingya\%20and\%20COVID-19\%20-\%20Tow ards $\% 20$ an $\% 20$ inclusive $\% 20$ and $\% 20$ sustainable $\% 20$ policy $\% 20$ res ponse.pdf

Star Online Report (2021) Rohingya issue: China and Russia for Myanmar, India abstains from voting. The Daily Star. https://www.theda ilystar.net/online/news/rohingya-issue-china-and-russia-myanm ar-india-abstains-voting-2021297

Stockholm Resilience Centre (2018) Ecosystem matter for development in the Anthropocene. Stockholm Resilience Centre Brief, May 2018. https://graid.earth/wp-content/uploads/2018/05/SUNI-201Brief-\%E2\%80\%93-Ecosystems-matter_webb.pdf

Taufiq HA (2019) China, India, and Myanmar: playing rohingya roulette? In: Hossain I (ed) South Asia in global power rivalry. Palgrave Macmillan, Singapore, pp 81-99

The Asia Foundation, Centre for Peace and Justice, BRAC University (2020) Navigating at the margins: family, mobility and livelihoods amongst Rohingya refugees in Bangladesh. The Asia Foundation, San Francisco and Centre for Peace and Justice, Dhaka

Truelove S, Abrahim O, Altare C, Azman A, Spiegel P (2020) COVID19: projecting the impact in Rohingya refugee camps and beyond. SSRN Electron J. https://doi.org/10.2139/ssrn.3561565

Uddin MA (2020) Local response to the global pandemic (COVID-19) in Bangladesh. SocAnthropol. https://doi.org/10.1111/1469-8676. 12888

UNCHA (2013) Myanmar: a country prone to a range of natural disasters. https://reliefweb.int/report/myanmar/myanmar-countryprone-range-natural-disasters- 0

UNDP (2018) Impacts of the Rohingya refugee influx on host communities. United Nations Development Programme, Dhaka

UNDP Bangladesh and UN WOMEN Bangladesh (2018) Report on Environmental Impact of Rohingya Influx. Dhaka, Bangladesh, p 106

UNHCR (2020) Refugee health workers lead COVID-19 battle in Bangladesh camps. Available via UNHCR. https://www.unhcr. org/en-us/news/stories/2020/7/5f198f1f4/refugee-health-worke rs-lead-covid-19-battle-bangladesh-camps.html

UNHCR Bangladesh Refugee Emergency Population Factsheet (15 Feb 2019)

UNGA (2020) Situation of human rights of Rohingya muslims and other minorities in Myanmar. United Nations, New York. http:// undocs.org/A/C.3/75/L.34

UN Environment Programme (2018) A precarious environment for the Rohingya refugees. https://www.unenvironment.org/news-andstories/story/precarious-environment-rohingya-refugees

UN OCHA (2020) The spaces between allah and science. https://www. humanitarianresponse.info/sites/www.humanitarianresponse. info/files/documents/files/covid-19_explained_-_edition_4_the_ spaces_between_allah_and_science.pdf

UN (2015a) Transforming our world: the 2030 agenda for sustainable development. Resolution adopted by the General Assembly on 25 September 2015. https://www.un.org/en/development/desa/ population/migration/generalassembly/docs/globalcompact/A_ RES_70_1_E.pdf

UN (2015b) 'Catastrophic' floods in Myanmar hit most vulnerable, including children-UN agencies. https://news.un.org/en/story/ 2015/08/505572-catastrophic-floods-myanmar-hit-most-vulne rable-including-children-un-agencies

UN (2017) UN human rights chief points to 'textbook example of ethnic cleansing' in Myanmar. UN News. 11 September 2017. Migrants and Refugees. https://news.un.org/en/story/2017/09/ 564622-un-human-rights-chief-points-textbook-example-ethniccleansing-myanmar. 11 Sept 2017

United Nations Human Rights Council (2016) Situation of human rights of Rohingya muslims and other minorities in Myanmar: report of the United Nations high commissioner for human rights. United Nations, New York. https://digitallibrary.un.org/record/ $846981 ? \ln =\mathrm{en}$

United Nations Human Rights Council (2018) Report of the independent international fact-finding mission on Myanmar. United Nations, New York. https://digitallibrary.un.org/record/1648304? $\ln =\mathrm{en}$

UoM (2015) The 2014 Myanmar population and housing census, Rakhine State Report, Census Report Volume 3-K. Nay Pyi Taw: Ministry of immigration and population, Union of Myanmar

Uqba S (2020) Islam's Prophet Muhammad's 'timeless' pandemic advice goes viral in 2020. The New Arab. https://english.alara by.co.uk/english/indepth/2020/4/20/islams-prophet-muhammadspandemic-advice-goes-viral-in-2020

Virji H, Sharifi A, Kaneko S, Simangan D (2019) The Sustainability-peace nexus in the context of global change. SustSci 14:1467-1468 
Ware A, Laoutides C (2018) Myanmar's 'Rohingya' conflict. Oxford University Press, New York

WFP (2017) Myanmar-food security assessment in the northern part of Rakhine state, July 2017. https://www.wfp.org/publi cations/myanmar-food-security-assessment-northern-part-rakhi ne-state-july-2017

Williams G, Mawdsley E (2006) Postcolonial environmental justice: government and governance in India. Geoforum 37(5):660-670

World Bank (2020) Population density (people per sq. km of land area)—Bangladesh. https://data.worldbank.org/indicator/EN.POP. DNST?locations $=\mathrm{BD}$
Zawacki B (2013) Defining Myanmar's "Rohingya problem.” Hum Rights Brief 20(3):18-25

Publisher's Note Springer Nature remains neutral with regard to jurisdictional claims in published maps and institutional affiliations. 